\author{
RENATA GALEK ${ }^{1}$ \\ BARTOSZ KOZAK $^{1}$ \\ DARIUSZ ZALEWSKI ${ }^{1}$ \\ EWA SAWICKA-SIENKIEWICZ ${ }^{1}$ \\ ADELA ADAMUS ${ }^{2}$ \\ AGNIESZKA KIELKOWSKA ${ }^{2}$ \\ ${ }^{1}$ Uniwersytet Przyrodniczy we Wrocławiu, Katedra Genetyki, Hodowli Roślin i Nasiennictwa \\ ${ }^{2}$ Uniwersytet Rolniczy w Krakowie, Zakład Genetyki, Hodowli Roślin i Nasiennictwa \\ Kierownik Tematu: dr hab. Renata Galek prof. nadzw. Uniwersytet Przyrodniczy we Wrocławiu, Katedra \\ Genetyki, Hodowli Roślin i Nasiennictwa, Zakład Genetyki i Biotechnologii Roślin, pl. Grunwaldzki 24a, \\ 50-363 Wrocław, tel. 713201815 lub 713201826, e-mail: renata.galek@upwr.edu.pl
}

Prace zostały wykonane $w$ ramach badań podstawowych na rzecz postępu biologicznego w produkcji roślinnej na podstawie decyzji Ministra Rolnictwa i Rozwoju Wsi nr HOR.hn.802.14.2018, Zadanie 108.

\title{
Badania nad gametyczną embriogenezą u Lupinus angustifolius L. - indukcja haploidów i analiza genetycznego podłoża tego procesu
}

\section{Research on gametic embryogenesis in Lupinus angustifolius L. - haploid induction} and analysis of the genetic basis of this process

\footnotetext{
Słowa kluczowe: androgeneza, gynogeneza, haploidy, identyfikacja haploidów, krzyżowanie oddalone, łubin wąskolistny
}

\section{WSTĘP}

Łubin wąskolistny obok łubinu żółtego jest podstawowym gatunkiem uprawnym $\mathrm{z}$ rodzaju Lupinus. Do wzrostu jego znaczenia $\mathrm{w}$ ostatnich latach przyczyniło się obniżenie poziomu alkaloidów $\mathrm{w}$ nasionach i wyselekcjonowanie form o polowej odporności na antraknozę. Jest on głównie uprawiany, jako roślina rotacyjna ze zbożami, oraz pastewna wykorzystywana w żywieniu zwierząt. Przełomem w badaniach genetycznych u łubinu wąskolistnego było wyprowadzenie przez badaczy australijskich rekombinowanych linii wsobnych RILs, co umożliwiło opracowanie pierwszej mapy genetycznej. Kolejnym krokiem w badaniach genetycznych było zsekwencjonowanie genomu odmiany Tanjil, której genom został przyjęty jako referencyjny dla tego gatunku. Istotnym również etapem było wyprowadzenie w latach 2002-2010 linii RILs techniką 
SDS, w oparciu o rodzime tło genetyczne (Katedra Genetyki, Hodowli Roślin i Nasiennictwa Wrocław) i skonstruowanie mapy genetycznej (Kozak, 2014).

$\mathrm{Na}$ tle osiągnięć u innych gatunków próby uzyskania haploidów i dihaploidów u Fabaceae są ciągle na etapie wstępnych badań. Z kilkuset gatunków zaliczanych do tej rodziny, zaledwie u 16 otrzymano zregenerowane pojedyncze rośliny haploidalne na drodze androgenezy wykorzystując kultury pylnikowe lub izolowane mikrospory. Przeprowadzone dotychczas prace skupiały się nad podniesieniem wydajności procesu haploidyzacji. Pierwsze haploidalne tkanki kalusa w androgenicznej kulturze pylników Pisum sativum otrzymali Gupta i współpracownicy 1972 roku. Następnie Mokhtaarzaden i Constantin (1978) opisali możliwość zastosowania kultur pylnikowych do wyprowadzenia haploidalnych roślin u Trifolium alexandrinum, Glycine max. W rodzaju Lupinus podejmowane były próby indukcji haploidów również w kulturach pylnikowych oraz izolowanych mikrospor, ale kończyły się tylko otrzymaniem tkanki kalusowej, wielokomórkowych struktur czy prozarodków (Omerod i Caligari, 1994; Skrzypek i in., 2008; Kozak i in., 2012). Opracowanie metod indukcji haploidów i dihaploidów przyczyniłoby się do postępu $w$ badaniach genetyczno-hodowlanych u łubinu wąskolistnego oraz poznania genetycznego podłoża haploidyzacji. Proponowany projekt badawczy stanowi nowość, ponieważ w światowej literaturze brak jest aktualnych informacji na temat poznania procesów gametycznej embriogenezy u tego gatunku.

\section{CEL BADAŃ}

Realizacja projektu w pierwszym roku badań - 2018 została podzielona na trzy części, których celami zasadniczymi były:

— analiza wpływu pyłku obcego gatunku oraz indukcji gynogenezy na rozwój komórek woreczka zalążkowego,

— charakterystyka procesu androgenezy u wybranych genotypów L. angustifolius oraz przygotowanie bibliotek cDNA,

— opracowanie zestawu markerów SNP do identyfikacji haploidów i linii homozygotycznych oraz 20 sekwencji sond do FISH.

\section{METODY BADAŃ}

W pierwszej części projektu do krzyżowania oddalonego wykorzystano 4 genotypy łubinu wąskolistnego ('Emir', 'Karo', 'Graf', LAE1) oraz pyłek dwóch genotypów łubinu andyjskiego (LM 13 oraz LM 34) i pyłek dwóch genotypów łubinu żółtego (500 oraz Prz1.). Słupki na drugi dzień po przepyleniu traktowano 2,4 D (100 mg/l). Z kwiatów usuwano przed zapyleniem oddalonym pylniki (jak osiągnęly $2 / 3$ długości szyjki słupka) a zapylania dokonywano na drugi i trzeci dzień. Dla prześledzenia zachowania się obcego pyłku zostały pobrane słupki/rozwijające się strąki po 48, 96 i 168 $\mathrm{h}$ od momentu przypylenia obcym pyłkiem. Materiał po utrwaleniu został przeznaczony do sporządzenia preparatów z wykorzystaniem błękitu aniliny i mikroskopu z fluorescencją. Prześledzono między innymi zachowania się pyłku na znamionach oznaczając 
intensywność osadzania się pyłku w skali od 1 do $3(1$ - pojedyncze ziarna pyłku 2 kilkanaście ziaren pyłku 3 - znamię prawie całe pokryte ziarnami pyłku), \% udział znamion z pyłkiem, \% udział znamion i szyjek słupka z przerastającymi łagiewkami, $\%$ udział zalążków $\mathrm{z}$ łagiewkami Do dalszych etapów projektu pozostały utrwalone preparaty do przeanalizowania zmian w zalążkach w roku 2019. Wykładano izolowane zalążki, $z$ ww. krzyżowań oddalonych na dwa rodzaje podłoży (P2 i P3), po wcześniejszej ich dezynfekcji. Po 30 dniach kultury określono \% udział zalążków regenerujących w tkankę kalusową, określono rodzaj tkanki kalusowej (I, II, III) i udział zalążków z poszczególnymi rodzajami, a także określono wielkość poszczególnych rodzajów tkanki kalusowej. Ponadto dla wybranych 4 genotypów zostały założone kultury in vitro zalążków po 2-3 dniach od momentu kastrowania dla zaindukowania procesu gynogenezy. W przypadku uzyskania regenerantów w układach krzyżowania oddalonego i gynogenezy przeprowadzono oznaczenia poziomu ploidalności za pomocą cytometru przepływowego CyFlow ${ }^{\circledR}$ Ploidy Analyser (Sysmex).

Ponadto w pierwszej części projektu dla sprawdzenia rozwoju zarodków zygotycznych w zależności od terminu izolacji były 4 ww. genotypy łubinu wąskolistnego, z których izolowano zarodki w dwóch terminach A - po 14 dniach od samozapylenia oraz B - 28 dniach. Dezynfekcji powierzchniowej poddawano całe strąki, a następnie izolowano zarodki na pożywkę MS, potem B5 z dodatkiem 0,6 g/1 węgla aktywnego. Po miesiącu od założenia kultury dokonano oceny rozwoju części podziemnej (obecność lub brak korzenia,) i nadziemnej (rozwój lub brak).

Do drugiej części projektu materiałem roślinnym do badań nad indukcją androgenezy były dwie odmiany L. angustifolius: Karo i Graf. W celu ustalenia optymalnego stadium rozwojowego mikrospor z kwiatostanów obydwu obiektów pobrano pąki kwiatowe o różnej długości w celu wytypowania pąków, w których występują mikrospory w fazie jednojądrowej - optymalnej do indukcji androgenezy. W pąkach oceniono stadium rozwoju pyłku poprzez obserwację preparatów rozgniotowych, barwionych DAPI i obserwowanych $\mathrm{W}$ mikroskopie fluorescencyjnym Axiovert S 100 wyposażonym w lampę HBO $50 \mathrm{~W} / \mathrm{AC}$ (Zeiss).

Następnie kwiatostany pobrane $\mathrm{z}$ roślin donorowych zawierające mikrospory w odpowiednim stadium podzielono na dwie części. $Z$ jednej części od razu po przyniesieniu do laboratorium pobierano pąki kwiatowe odkażano i prowadzono procedurę izolacji mikrospor. Natomiast drugą część kwiatostanów poddano wstępnemu traktowaniu poprzez chłodzenie przez 1 lub 3 dni w temperaturze $4^{\circ} \mathrm{C}$ i po tym czasie odkażano i prowadzono izolację mikrospor. Mikrospory w pożywce NLL lub MS umieszczano w termostacie w temperaturze $32^{\circ} \mathrm{C}$ lub $4^{\circ} \mathrm{C}$ na 1 lub $3 \mathrm{dni}$ bez dostępu światła. Następnie szalki przenoszono do temperatury $25^{\circ} \mathrm{C}$. Po około trzech tygodniach szalki z termostatu przenoszono na wytrząsarkę (ok. $30 \mathrm{rpm}$ ), gdzie pozostawały do końca kultury.

W drugiej części tego zadania zaplanowano utworzenie biblioteki cDNA, do w przyszłości analizy ekspresji genów. W pierwszym roku badań całkowite RNA wyizolowane zostało z mikrospor dwóch genotypów łubinu wąskolistnego (Graf i Karo) w początkowych etapach mikrosporogenezy (stadium jednojądrowe) i androgenezy (ziarna pyłku po stresie temperaturowym). Do izolacji wykorzystany został zestaw 
Total RNA Mini (AA Biotechnology). Jakość wyizolowanego RNA sprawdzono za pomocą zestawu Qiaxcel RNA QC kit v2.0 (Qiagen) na urządzeniu QIAxcel. Na urządzeniu Qiaxcel zmierzone zostały również takie parametry jak RIS oraz stężenie całkowitego RNA. Wyizolowane RNA przepisano na cDNA w reakcji odwrotnej transkrypcji. Reakcję przeprowadzono za pomocą zestawu TranScriba (AA Biotechnology) zgodnie z instrukcją producenta.

Do trzeciej części badań w pierwszym roku wykorzystano wybrane linie RILs (20 linii) wyprowadzone metodą SDS w KGHRiN. Markery SNP (80) do oceny stopnia homozygotyczności pochodziły z puli markerów opracowanych dla łubinu wąskolistnego w ramach badań prowadzonych w KGHRiN. Do badań wybrano markery o najwyższej wartości PIC. Dodatkowym istotnym kryterium podczas ich wyboru była lokalizacja na mapie genetycznej „ExL” opracowanej w ramach badań prowadzonych w KGHRiN. Genomowe DNA do genotypowania zostało wyizolowane za pomocą zmodyfikowanej metody CTAB (Clements i in., 2013). Loci SNP genotypowano metodą KASP z wykorzystaniem odczynnika KASP MasterMiX KBE V2.0 (LCG Genomic) zawierającego wszystkie niezbędne składniki reakcji. Genotypowanie przeprowadzono na urządzeniu Ilumina Eco. Genotyp oznaczano manualnie w programie ilumina ECO, a następnie eksportowano jako pliki tekstowy do dalszych analiz. Przygotowanie sond FISH zostało wykonane na podstawie sekwencji genomowych oraz markerów SNP z mapy „ExL”. W tym celu dla każdego chromosomu łubinu wąskolistnego z genomu referencyjnego (Hane i in., 2017) wybrana została jedna odpowiadająca mu grupa sprzężeń z mapy 'ExL'. Dla każdej z 20 wyselekcjonowanych w ten sposób grup wybrane zostały markery lokalizujące się w środkowej części grupy. W kolejnym etapie sekwencje wybranych markerów przyrównano do genomu referencyjnego łubinu wąskolistnego (Hane i in., 2017) za pomocą algorytmu BLASTn (Altschul i in., 1990). W ten sposób wybrane zostały fragmenty genomu referencyjnego długości do $15 \mathrm{kpz}$ dla których przygotowane zostaną sondy FISH wykorzystane w analizach w kolejnych etapach projektu. Analizy markerów, BLASTn oraz wybór odpowiednich fragmentów genomu referencyjnego wykonano po utworzeniu skryptu języka Python (https://www.python.org/) z wykorzystaniem bibliotek pandas (https://pandas.pydata.org/), NumPy (http://www.nu mpy.org/), Biopython (https://biopython.org/) oraz pybedtools (https://daler.github.io/pyb edtools/index.html).

\section{WYNIKI}

W pierwszym roku badań na wstępie konieczne było poznanie i określenie możliwości synchronizacji terminów kwitnienia w kontrolowanych warunkach w szklarni oraz polu form matecznych oraz gatunków używanych jako zapylaczy w krzyżowaniu oddalonym. $\mathrm{Z}$ uwagi na to przeprowadzono wysiew w warunkach szklarniowym oraz polowych wybranych genotypów. Obserwacje dowiodły, że rośliny L. mutabilis trzeba wysiewać wcześniej o 3 tygodnie od L. angustifolius a L. luteus o dwa. Optymalne stadium rozwojowe woreczka zalążkowego zostało ustalone w oparciu o porównanie zmian zachowania się okwiatu w procesie samozapylenia i zmian morfologicznych w kolorze 
płatków w porównaniu do zmian w trakcie nanoszenia obcego pyłku na znamiona L. angustifolius. W pierwszej części projektu przeanalizowano wpływ pyłku obcego gatunku — łubinu żółtego (52 chromosomy) oraz łubinu andyjskiego (48 chromosomów) na rozwój woreczka zalążkowym po zapyleniu roślin łubinu wąskolistnego (40 chromosomów). U odmiany Emir pyłek średnio najwięcej osadzał się przy wykorzystaniu jako zapylacza L. mutabilis - LM 13 oraz L. luteus - 500 - 54-58\%, 1,4-1,3 w skali. Dla 'Karo' najlepsze osadzanie się pyłku stwierdzono po użyciu jako donora pyłku do zapylania L. luteus - 500 (75\%), zaś dla LAE1 L. mutabilis - LM 34 (67\%). Na słupkach 'Karo' odnotowano najlepszą intensywność osadzania się pyłku średnio 1,6. Interesujące wyniki uzyskano dla 'Graf', gdyż \% udział słupków z osadzonym pyłkiem był porównywalny we wszystkich czterech układach krzyżowania i w trzech zawierał się $54 \%$ do $64 \%$ z 2 do 1,6-stopniową oceną intensywnością osadzania się pyłku. Wykorzystanie krzyżowania oddalonego $\mathrm{w}$ niniejszym projekcie odniosło zdecydowanie pozytywny wpływ na rozwój strąków, co skutkowało rozwojem tkanki kalusowej z zalążków, w tym haploidalnej. Zalążki izolowane po 2-3 dniach od usunięcia pylników, nie poddane działaniu pyłku obcego gatunku nie podjęły regeneracji $\mathrm{w}$ zadawalającym procencie. Zastosowanie cytometrii przepływowej nie umożliwiło identyfikacji poziomu ploidalności tkanki kalusowej, z uwagi na jej znikomą ilość. Badania nad indukcją procesu gynogenezy będą kontynuowane w kolejnych etapach projektu.

U zalążków otrzymanych z krzyżowania oddalonego obserwowano 3 rodzaje kalusa: igiełkowaty I, kryształkowy II, uwodniony III. Zalążki regenerowały $\mathrm{z}$ różną częstotliwością w zależności od genotypu, układu krzyżowania oddalonego i rodzaju pożywki. U odmiany Emir największy odsetek zalążków ze zmianami po 30 dniach $98 \%$ obserwowano w przypadku użycia jako zapylacza L. luteus 500 na obu rodzajach pożywki - P2 i P3, co okazało się zbieżne z wynikami dla osadzania się pyłku przy tym układzie krzyżowania. Przeważał u tego obiektu rodzaj III i II tkanki kalusowej o wielkości 1-5 mm. Dla 'Graf' pyłek L. luteus 500 również okazał się najkorzystniejszym zapylaczem, ponieważ powodował regenerację $63 \%$ oraz $78 \%$ zalążków odpowiednio na pożywce P3 i P2. U zalążków tego genotypu dominował 3 rodzaj tkanki kalusowej, a jej rozwój był znacznie słabszy $(0,5-2 \mathrm{~mm})$ niż u odmiany Emir. Zalążki 'Karo' uległy w największym stopniu zmianom biorąc pod uwagę rozwój kalusa we wszystkich wariantach zapylaczy i zastosowanej pożywki. Wielkość rozwijającej się tkanki była stosunkowo obfita we wszystkich wariantach w porównaniu do innych obiektów. Przeważał rodzaj II i III. Zalążki LAE-1 pozytywnie zareagowały na zastosowane zapylacze, ale wyraźnie ograniczający wpływ miała pożywka.

Uzyskane wyniki z cytometru przepływowego wskazały, że regenerujący kalus był na poziomie $1 \mathrm{x}$ oraz $2 \mathrm{x}$ na każdym $\mathrm{z}$ analizowanych zalążków. Tylko $\mathrm{w}$ przypadku regenerujących zalążków odmiany Karo $\times$ L. mutabilis LM 13 oraz linii LAE-1 $\times$ L. luteus 500 na pożywce P2 poziom ploidalności był 1x. Badania w zakresie zmian w woreczku zalążkowym jako rezultatu krzyżowania oddalonego są zaplanowane w następnych etapach projektu. W tym przypadku możemy mieć do czynienia z partenogenezą indukowaną lub eliminacją chromosomów z zarodka mieszańcowego. 
Zweryfikowanie tego stanowiska będzie możliwe po przeanalizowaniu preparatów sporządzonych z utrwalonych zalążków. Wcześniejsze badania związane z otrzymywaniem mieszańców oddalonych w rodzaju Lupinus nie dały jednoznacznej odpowiedzi czy mamy do czynienia $\mathrm{z}$ procesem haploidyzacji czy otrzymywaniem mieszańców oddalonych (Przyborowski i Packa, 1997; Przyborowski, 2003; Wilson i in., 2008; Galek, 2010). Konieczne będzie też dopracowanie pożywek dla konwersji komórek tkanki kalusowej w rośliny na drodze morfo i organogenezy

Rozwój zarodków zygotycznych pobranych po 14 dniach od momentu samozapylenia przebiegał wolniej niż pobranych po 28 dniach. Ponadto obserwowano spore zaburzenia w rozwoju systemu korzeniowego u wcześniej wyizolowanych zarodków zygotycznych - stadium A. Część pędowa rozwijała się u wszystkich zarodków, które formowały korzenie. Zarodki pobrane $\mathrm{w}$ starszym stadium charakteryzowały się lepszym ukorzenianiem powyżej $70 \%$ i długością korzeni od 2 do $3,6 \mathrm{~cm}$ po 14 dniach kultury. Zarodki pobrane w stadium A ukorzeniały się w zakresie od 31 do $75 \%$ a średnia długość korzeni była o $1 \mathrm{~cm}$ krótsza. Zarodki zygotyczne podjęly regenerację i konwersję w rośliny zwłaszcza, gdy użyto starszych zarodków (28 dni od samozapylenia), co z pewnością można wykorzystać do przyśpieszenia otrzymywania linii homozygotycznych na drodze SDS.

Zebrane wyniki dotyczące analizy mikrosporogenezy, w celu ustalenia optymalnego stadium rozwojowego mikrospor do założenia kultury, wskazują że u tubinu wąskolistnego czynnikiem bardziej skorelowanym ze stadium rozwojowym mikrospory jest barwa pylnika, nie jak u innych gatunków, u których indukowano androgenezę wielkość pąka kwiatowego (Dujis i in., 1992). Ponadto badania wykazały, że rozwój mikrospor $\mathrm{W}$ indywidualnym pąku jest niesynchroniczny. W pylnikach pobranych $\mathrm{z}$ indywidualnego pąka obserwowano różne stadia rozwojowe, np. tetrady, mikrospory i dojrzałe ziarna pyłku. Uzyskane wyniki potwierdzają doniesienia literaturowe dla łubinu (Kozak i in., 2012) jak i innych gatunków z rodziny strączkowych (Croser i in., 2006). Stan taki stwarza trudności w uzyskaniu jednorodnej zawiesiny komórek w celu indukcji androgenezy w kulturach mikrospor. Kolejnym problemem było uzyskanie właściwej gęstości kultury. Jak podaje literatura w celu stymulacji rozwoju mikrospor roślin strączkowych wymagana jest stosunkowo wysoka gęstość zawiesiny wynosząca ok. 100 tys. mikrospor/ ml pożywki (Bayliss i in., 2004; Ochatt i in., 2009; Croser i in., 2006). Uzyskane wyniki wykazały, ze w całym kwiatostanie w którym przeciętnie znajduje się od 14-20 pąków tylko średnio $2 \mathrm{z}$ nich zawierały mikrospory w optymalnym stadium do indukcji androgenezy. Stan taki powoduje zużycie dużej liczby materiału roślinnego efektem, czego było założenie 1 do 2 szalek z pojedynczej izolacji. Jest to sytuacja bardzo odmienna $\mathrm{w}$ porównaniu do np. roślin kapustnych gdzie $\mathrm{z}$ pojedynczego kwiatostanu można uzyskać znaczną liczbę pąków dającą gwarancję założenia kultur obejmujących znaczącą populację komórek (Custers, 2003). W niniejszych badaniach zastosowano stres temperaturowy aplikowany zarówno na kwiatostany, jak i mikrospory w kulturze. Pomimo zastosowania zróżnicowanych kombinacji doświadczenia (szoki temperaturowe, pożywki) w większości kultur obserwowano brak rozwoju mikrospor. W nielicznych przypadkach udało się zaindukować podziały mikrospor, które doprowa- 
dziły do otrzymania kalusa, co jest obiecujące, gdyż dotychczas opisane próby indukcji haploidów za pomocą androgenezy kończyły się otrzymaniem struktur wielojądrowych lub struktur zarodkopodobnych, które nie podejmowały dalszego rozwoju (Croser i in., 2006; Skrzypek i in., 2008; Kozak i in., 2012).

Dla obu badanych genotypów uzyskane wartości stężenia i RIS pozwalają stwierdzić, że wyizolowane RNA nadawało się do utworzenia biblioteki cDNA, a następnie w kolejnym etapie do zsekwencjonowania i analiz DE (differential expression - analiza zróżnicowania ekspresji). Proces izolacji nie był łatwy, z uwagi na konieczność nagromadzenia dużej liczby mikrospor, co w przypadku łubinu wąskolistnego nie jest rzeczą łatwą.

Ilość i jakość RNA ma kluczowe znaczenie dla powodzenia eksperymentów typu RNAseq. Jakość RNA wpływa na jakość przygotowanej biblioteki. Biblioteki złej jakości nie pozwalają na generowanie odczytów wysokiej jakości w procesie sekwencjonowania. Odczyty słabej jakości nie pozwalają na przeprowadzenie wiarygodnej analizy DE (Wang i in., 2009; Wang i in., 2012). Dlatego tak ważne jest uzyskanie po izolacji RNA wysokiej jakości. Ponadto stężenie i jakość RNA muszą zostać precyzyjnie określone. W przypadku przygotowywania próbek do analiz RNAseq standardem jest kontrola RNA przy pomocy urządzenia bioanalyzer (Udvardi i in., 2008). Nie mniej jednak na rynku istnieją także inne systemy, które mogą z powodzeniem zostać wykorzystane do kontroli jakości próbek RNA. Jednym z takich systemów jest Qiaxcel RNA QC kit v2.0 (Sidova $\mathrm{i}$ in., 2015; Unger i in., 2015). Do określenia jakości RNA za pomocą Qiaxcel RNA qC kit v2.0 służy parametr RIS (RNA Integrity Score) określający stosunek $18 \mathrm{~S}$ rRNA do $28 \mathrm{~S}$ rRNA (Sidova i in., 2017). System ten został wykorzystany $\mathrm{z}$ powodzeniem $\mathrm{w}$ naszych badaniach.

Genotypowanie markerami SNP 20 wybranych linii RILs za pomocą 80 markerów SNP pozwoliło na ocenę stopnia homozygotyczności wybranych linii. Na 20 analizowanych linii 18 wykazało pełną homozygotyczność w 80 badanych loci. Dwie analizowane linie wykazały heterozygotyczność w trzech (linia EL/02/1/53) oraz pięciu (linia EL/02/1/7) analizowanych loci. Analiza markerów DArTseq pozwoliła na wytypowanie 46 z nich zlokalizowanych w centralnej części grup sprzężeń mapy ExL. Najwięcej markerów zlokalizowanych było na chromosomie NLL-16 - 9 markerów. Na ośmiu chromosomach zlokalizowano po jednym markerze (NLL-01, NLL-02, NLL-03, NLL04, NLL-07, NLL-09, NLL-10, NLL-18). Na pozostałych chromosomach lokalizowało się od 2 do 4 markerów. Sekwencje sond zapisano w pliku fish.fasta. Osiemnaście z dwudziestu sond mają długość $15 \mathrm{kpz}$, natomiast sondy chromosomu NLL-05 oraz NLL-08 $9710 \mathrm{pz}$ oraz $8826 \mathrm{pz}$. W obrębie 15 sond zlokalizowanych zostało po jednym markerze DArTseq. Dla pozostałych były to dwa lub trzy markery. Opracowane markery i sondy FISH będą podstawą w przyszłości do identyfikacji haploidów, czy podwojonych haploidów.

\section{WNIOSKI}

1. Zarodki zygotyczne podjęły regenerację i konwersję w rośliny zwłaszcza, gdy użyto starszych zarodków (28 dni od samozapylenia), co z pewnością można wykorzystać 
do przyśpieszenia otrzymywania linii homozygotycznych $\mathrm{z}$ wykorzystaniem procedury SDS.

2. Generalnie pyłek obcych gatunków osadzał się na znamionach analizowanych 4 genotypów L. angustifolius, kiełkował i docierał do zalążka. Procesy te przebiegały w różnym nasileniu. Planowane badania w roku 2019 powinny dostarczyć informacji, czy mamy do czynienia z powstawaniem zygot i późniejszą eliminacją chromosomów czy partogenezą.

3. Jako zapylacza proponuje się pyłek L. luteus $500 \mathrm{w}$ krzyżowaniach oddalonych lub L. mutabilis LM 34.

4. Zalążki 'Karo' uległy $w$ największym stopniu zmianom biorąc pod uwagę rozwój kalusa we wszystkich wariantach zapylaczy i zastosowanej pożywki.

5. Uzyskano przy wykorzystaniu krzyżowania oddalonego kalus na poziomie $2 \mathrm{x}$ i $1 \mathrm{x}$, a tylko $\mathrm{w}$ przypadku regenerujących zalążków odmiany Karo $\times$ L. mutabilis LM 13 oraz linii LAE- $1 \times$ L. luteus 500 na pożywce $\mathrm{P} 2$ poziom ploidalności był $1 \mathrm{x}$.

6. Optymalne stadium rozwojowe do zakładania kultur izolowanych mikrospor znajduje się w środkowej części kwiatostanu.

7. Odmiana Graf w kulturze pylników okazała się przydatna do indukcji tkanki kalusowej, aczkolwiek zbyt mała jej ilość nie pozwoliła na ocenę poziomu ploidalności.

8. Izolacja RNA i utworzenie biblioteki cDNA daje podstawy do kontynuowania badań nad genetycznym podłożem procesu androgenezy.

9. Opracowane markery i sondy FISH będą podstawą do identyfikacji haploidów, czy podwojonych haploidów.

\section{LITERATURA}

Altschul S. F., Gish W., Miller W., Myers E. W., Lipman, D. J. 1990. Basic local alignment search tool. Journal of Molecular Biology 215 (3): $403-410$.

Bayliss K. L., Wroth J. M., Cowling W. A. 2004. Pro-embryos of Lupinus spp. produced from isolated microspore culture. Aust. J. Agric. Res. 55: 589 - 593.

Clements J., Galek R., Kozak B., Michalczyk D. J., Piotrowicz-Cieślak A. I., Sawicka-Sienkiewicz, E., Zalewski, D. 2014. Diversity of selected Lupinus angustifolius L. genotypes at the phenotypic and DNA level with respect to microscopic seed coat structure and thickness. PloS one, 9(8), e102874.

Croser J. S., Lulsdorf M. M., Davies P. A., Clarke H. J., Bayliss K. L., Mallikarjuna N., Siddique K. H. M. 2006. Toward doubled haploid production in the Fabaceae: progress, constraints, and opportunities. Crit. Rev. Plant Sci. 25: $139-157$.

Custers J. B. M. 2003. Microspore culture in rapeseed (Brassica napus L.). In: Maluszynski M., Kasha K.J., Forster B. P., Szarejko I. (eds) Doubled haploid production in crop plants. Springer, Dordrecht, 2003: $185-193$.

Duijs J. M. G. J., Voorrips R. E., Visser D., Custers J. B. M. 1992. Microspore culture is successful in most crop types of Brassica oleracea L. Euphytica 60: $45-55$.

Galek R. 2010. Studia nad zmiennością wybranych cech morfologicznych i użytkowych rodzaju Lupinus, ze szczególnym uwzględnieniem mieszańców wewnątrz i międzygatunkowych. $122 \mathrm{~s}$

Hane J. K., Ming Y., Kamphuis L. G., Nelson M. N., Garg G., Atkins C. A., Edwards D. 2017. A comprehensive draft genome sequence for lupin (Lupinus angustifolius), an emerging health food: insights into plant-microbe interactions and legume evolution. Plant Biotechnology Journal 15 (3): 318 -330 . 
Kozak B. 2014. Charakterystyka markerów molekularnych przydatnych do selekcji wybranych cech u łubinu wąskolistnego (Lupinus angustifolius L.). Rozprawa doktorska.

Kozak K., Galek R., Waheed M.T., Sawicka-Sienkiewicz E. 2012. Anther culture of Lupinus angustifolius: callus formation and the development of multicellular and embryo-like structures. Plant Growth Regul 66: $145-153$.

Lichter R. 1982. Induction of haploid plants from isolated pollen of Brassica napus. Pflanzenphysiol 105: $427-434$.

Murashige T., Skoog F. 1962. A revised medium for rapid growth and bio assays with tobacco tissue cultures. Physiol. Plant. 15: $473-497$.

Ochatt S., Pech C.., Grewal R., Conreux C., Lulsdorf M., Jacas L. 2009. Abiotic stress enhances androgenesis from isolated microspores of some legume species (Fabaceae). J. Plant Physiol. 166: 1314 - 1328.

Ormerod A. J., Caligari, P. D. S. 1994. Anther and microspore culture of Lupinus albus in liquid culture medium. Plant cell, tissue and organ culture, 36 (2): $227-236$.

Przyborowski A. J., Packa D. 1997. Embryo development after interspecific hybrydisation of Lupinus albus L., L. mutabilis Sweet and L. angustifolius L. J. Appl. Genet. 38 (2): $131-141$.

Przyborowski J. A. 2003. Pre- i postzygotyczne bariery przy krzyżowaniu wybranych gatunków z rodzaju Lupinus. Rozprawy i Monografie. 78: $1-53$.

Sidova M., Tomankova S., Abaffy, P., Kubista, M., Sindelka, R. 2015. Effects of post-mortem and physical degradation on RNA integrity and quality. Biomolecular detection and quantification 5:3 3 - 9 .

Skrzypek E., Czyczylo-Mysza I., Marcińska I., Wędzony M. (2008). Prospects of androgenetic induction in Lupinus spp. Plant Cell Tissue Organ Cult. 94: 131 - 137.

Udvardi M. K., Czechowski T., Wolf-Rüdiger S. 2008. Eleven 2008 rules of quantitative RT-PCR. The Plant Cell 20, 7: $1736-1737$.

Unger C., Kofanova O., Sokolowska K., Lehmann D., Betsou, F. 2015. Ultraviolet C radiation influences the robustness of RNA integrity measurement. Electrophoresis 36 (17): $2072-2081$.

Wang L., Shengqin W., Li W. 2012. RSeQC: quality control of RNA-seq experiments. Bioinformatics 28.16: $2184-2185$.

Wang Z., Gerstein M., Snyder M. 2009. RNA-Seq: a revolutionary tool for transcriptomics. Nature Reviews Genetics 10,1: 57.

Wilson J. G., Clements J. C., Quealy J., Yang H. 2008. Development of an interspecific hybridization protocol for Lupinus. Proc. of the $12^{\text {th }}$ Int. Conf., Fremantle, Western Australia 14-18 September 2008: $147-151$. 
